\title{
抄碌
}

\section{1． 化學工業用機械及實驗裝置}

\section{不飽和及び芳香族岸化水素斣の測定用ピュレツト}

之に用ひられてわた從來の Kräme-Bottcher の装置

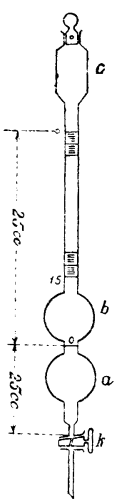

は不便であ万故に著者は圖の如きものお 考案した、即 $5 a, b$ 二つの球部、 $K$ の 括栓、25cc の容量の $C$ の部分よりなる

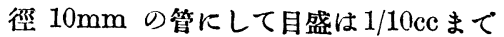
$15 \mathrm{cc}$ 附す、 $a, b$ の中間の $O$ の印の所 まて一定の比重の硫酸各 $20^{\circ}$ て入れ其 の上に試驗する油㤂目盛の零の所まで入 れろ、此の時硫酸化によりて熱后發生し て厴が高くならが之は最上の栓の小孔よ り除く、C は油と硫酸と施振つてよく混 合せしも万部分である、硫酸化が終つて からビュレットな $20^{\circ}$ に冷却し硫酸方下 の栓より 0 所まで下げ油の減量各目盛によりて瀆む のであろ (J. Formånck, Chem. Ztg., 1930, 54, 94, 908)

(小田)

或種鐵合金の電䐎一時間曲線 著者は金屬つ passivity の研究に於て鐵合金の電雁一時間曲線心求屯るに 次圖の如寻装により良結果が得られたと云つてる 万、眞空管は Mullard No. PM. 252. スウィッチS

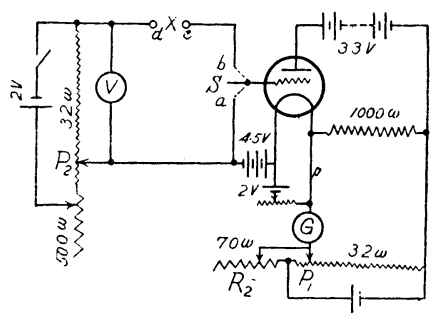
卡 $a$ の位置に 置く時はグリッ ドは 4.5 ボルド て僅かなプレー 卜雷流が流れ抵 抗 $R_{1}$ に電㕎降 ドが起りガルバ ノメーターGは

振れろ、故にポテンシオメーター $P_{1}$ 方適當に調節し て $G$ の振れる零とし $S$ を $b$ の位置に切換へ万と再 び $G$ は振れろから $P_{2}$ 龙適當に調節して $P_{2}$ の電位 が E.M.F.の $e$ 極の電位と等しくなれは $G$ は零死指 すから其の時の $P_{2}$ の電壓降下をボルトメーターて測 定すろのであろ (L. C. Bannister and U.R. Evans, J. Chem. Soc., 1939, 1361)

(森 安)

\section{硝子電極による $\mathrm{pH}$ 值測定への新型三極真空管の} 應用 一般にグリッド迴路に高抵抗（グリッドとフィ ラメントの抵抗に匹敵すへぎ を入れると異空管の特 性曲線は抵抗の無い場合に比し著しく警化寸、(第一圖 $\mathrm{A}$ 及 $\mathrm{B})$ 從つて确子の吅寻高抵抗電極 $\left(10^{6}-10^{8}\right.$ 才 一ム）方使用寸万時にはその抵抗の影響によ万特性曲 線の變化方求め補正すべき電㕓の大きさ $V$ 古知つて

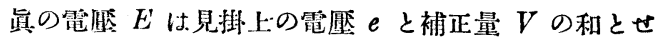
々ばなら奴、具つ确子電極の抵抗がグリッドとフィラ メントの間の抵抗と同じ order の大いさであれば極 の矿自面に電位差が生ずれば㨁ちに漏洩するが碍子電 極の抵抗及ワリッド電流か可及的小さくすれば $\mathrm{A}$ 曲 線は $\mathrm{B}$ 曲線に接近して來ろ、著者は $\mathrm{SiO}_{2} 60 \%$ 、

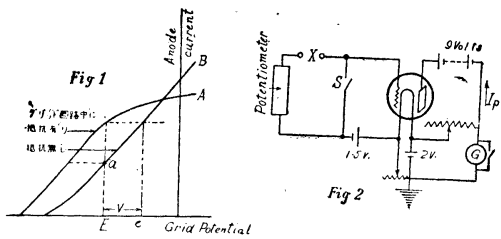

$\mathrm{Na}_{2} \mathrm{CO}_{3} 30 \% 、 \mathrm{CaCO}_{3} 10 \%$ より製作した碹子走使用 して 400 乃至 103 メグオーム以下の抵抗の極唯製作し た、抬黃空管の極の配置が變へて (グリッドかフィラ メントとプレートの間に置かない)グリッド電厴がー2 ホルトの時グリッド電流が $10^{-14} \mathrm{amp}$ のもの方作く ろことが出來たと云つてかる、此の黃空管杂用ふ万時 はグリッド廹路中に高抵抗が入つても殆んど特性曲線 が變らないこと、プレート電壓（4〜9ボルト）及フィ ラメント電流 $(0.7 \mathrm{amp})$ が小さいことが特色てある、 全體の接續は第二圖の通 $\mathfrak{} d I_{p} / d E_{g}=0.03$ milliamp/ per volt ておろ (G. B. Harris on, J. Chem. Soc., 1930, 1528)

(森 安)

\section{8. セメント及建築材料}

セメント製造に於て回博墅に就ての研究 燒成帶に

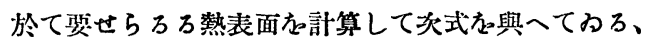
即ち 1 時間に燒塊 Mt を作ろに、總ての石宸を燒成

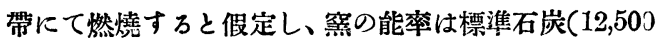


B.T.U/lb) $1 \mathrm{lb}$ を燃燒して $y \mathrm{lb}$ の燒塊る生ずるとし て、燒成帶に必裂なる表面林

$$
S=315.7 M / y \mathrm{ft}^{2}
$$

$y=3 \mathrm{lb}$ とすれば、 $S=1052 M \mathrm{it}^{2}$ となる

次に㨁徑を $d^{\prime}$ (煉瓦表面から煉瓦表面まて)として

$$
M=0.1123 d^{2} \text { 或は } d=2.98 \sqrt{ } \bar{M}
$$

燒成高 $\mathrm{Mt} / \mathrm{hr}$ 對して燒成带の必兹なる長さか $L$ 、 表面杂 $S$ として

$$
S=\pi d L \quad L=\frac{S}{\pi d}
$$

之に $S=105.2 M, d=2.98 \sqrt{M}$ か代入して

$$
L=11.24 \sqrt{M} \text { な得たり }
$$

(Geoffrey Martin, Rock Products, 1930, 33, No. 21)

（赤 非）

セメント製造に於て同轉㷊に就ての研究一熱力學數

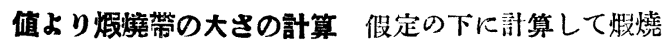
帶の壁より輻射する總熱量は、椵燒帶の總表面る $S^{\prime}$ として 43,35.9S B.T.U/hr, 燒塊 $1 \mathrm{lb}$ 炛作万に煆燒帶 に於て、原料の吸收寸万總熱量は 960.6B.T.U 危得、 次に $\mathrm{Mt} / \mathrm{hr}$ の燒塊龙作万に椵燒帶に於て项せられる 表面龙計算せり、即 5 燒塊 $y$ lb 12,630B.T Uの石 宸 $11 \mathrm{~b}$ 年裂すとせば $\mathrm{Mt} / \mathrm{hr}$ の燒塊には $2,249 \mathrm{M} / \mathrm{y} \times$ $12,600=28.23 \times 10^{6} \mathrm{M} / \mathrm{y}$ B.T.U $/ \mathrm{hr}$ 方必装とす、途中 支省略して $S=M\left[\frac{651}{y}-49.63\right]$

となり、 $y=3 \mathrm{lb}$ として $S=167.4 M$ となろ

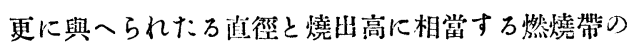
長さ $L$ 占求めたり、即ち

㨁徑虎 $d^{\prime}$ とせば $S=\pi d L, L=S / \pi d$

そに $d=2.98 \sqrt{M}, S=167.4 M$ 名代入して $L=$ $17.88 \sqrt{M^{\prime}}$

得たり (Geoffrey Martin, Ruck Products., 1930, 33, No. 22) （赤 井）

セメント製造に於て回轉哭に就て研究 著者は筧の 直徑と長さとの關係㤂次の式て與へてわる、

$$
\begin{aligned}
& L=25(d-1.5)+0.2(d-1.5)^{2} \cdots \cdot \text { 瀑式 } \\
& L=20(d-1.5)+0.2(d-1.5)^{2} \cdots \cdot \text { 乾式 }
\end{aligned}
$$

式中 $L^{\prime}=$ 窑の長さ、 $d^{\prime}=$ 煆燒帶及び乾燥帶に於ける

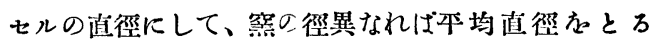
(Geoffrey Martin, Rock Products, 1930, 33, No. 23)

（赤 井）

原料ミルに依る粉碎に就て セメント工業にては次 の 3 點が問題となる、即 5 1. 原料 2 . 燃料 3. セメ
(1) 原料は出來ろだけ低溫度て本融さ寸篇に出來る だけ微粉にすること、而して山來万だけ粒子の大いさ か均一にす万事が大切である、この䈍複式ミルより風 分離器各有す万ミ儿の方が利である

（2）燃料は立窐ては大なり小なり粉碎して原料と混 合して小型虑作つて案に入れろ、此の型の大いさは燒 成時阔に關係が深いが現今は長さ 3)〜 40mm、直魶 $15 \mathrm{~mm}$ のしのが連續作業にて行はれてょろ、迴轉窨 にては粉末にして使用すっがその粉末度は燃料の揮發 分に依つて異万、同時に全部燃燒す万傜に粒子か子出來 ろだけ均一にすることが大切である、この點よりして 風分離器が利である

（3）セメントは矢張り風分距器方有するミルにて粉 碎寸万方が複式 3 空ミルに依るより利でらる、著者は

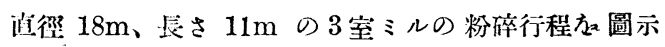
して之を镜明してゅろ、著者は現今第一級のセメント

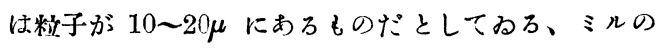

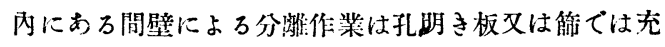
分でないので次第に針金式中間箱 (Drahtgewebe Zwischensichtung) に移行しつつおる (Ziment, 1930, 870)

(渡 漫)

\section{か熱せる場合三石灰硅酸掔の分解に及ぼす石亮の影}

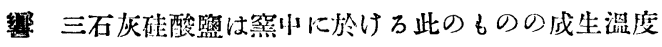

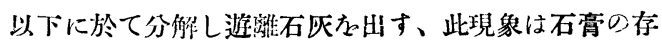
在に依つて促進せしめられろ、此の事賽よりして燒塊 中の三石灭礘酸監の量方测定し後、著者は第一表にて No. 1, No. 2, No. 3 の 3 種凹焼塊の分析各示し、第二 表には石骨方 0 〜 $12 \%$ まで加へたる燒塊を0〜32 時 間に $1000^{\circ} \mathrm{C}$ 熱したろ時の遊濰石灰の量方、第三表は 1.89 10.62\%の石高方加へた万ものの熱灼せざる場 合と 32 洔間熱灼せし場合との $\mathrm{SO}_{3}$ の差品、第四表 には石育か 3 時閒、20 時間、32 時間熱した場合の $\mathrm{SO}_{3}$ と遊滩石灰との關係か示してらろ、本實驗の結

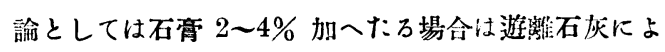
ろ三石灰硅酸量と計算によるものとがよく一致するが これ以上のるのにては一致せず、而て石高少量の時は

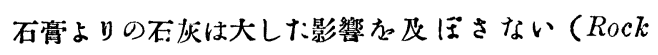
Product, 1939, 18, 621)

(渡 邊)

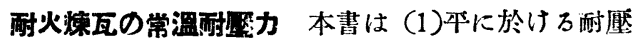
煉瓦の耐厘力か橫或は縱に於け万耐壓力に換算し得さ

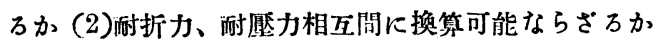
(3) 有孔度と䀽壓力とは相關せるるのには非ざかか、 


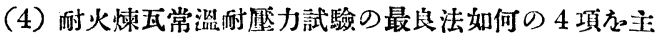
眼とし其供試骽として 6 種(本乾式厚搾製、混練再㕄 售製、手工製各 2 種）123 個の耐火煉瓦叴使用せ万 研究に關してのものなり、其結諭として下記の條々な 列學せり、(1)測定せ万有孔度の小範園內にては有孔度 と敷座力或は破壇率(Moduli of Rupture)との間には 何等數學的關係の存在す万事なし、(2)平、横、縱に於 けろ耐䝠力間には何等數學的關保の存在する事なし、

（3）破壞率と酎壓力との阔には何等數學的關係の存在 する事なし、(4)柇厴力は縱つ方向に就て試羷す万る可 とす、(5 硫黄と珄砂とか同量に配合せ万るのは酎厘力 試驗用カップとして最良好なり(Himansu K. Mitra, The Enginesring Experiment Station Bulletin, 193!, No. 54, Ohio State University) (山 摆)

\section{9. 石油及アスファルト}

石油溜分の成分に就て、低沸嚜ナフテンーパラフィン 混合物のアニリン㬴測定 ナフテンーバラフィン混合 物のアニリン點よりナフテンの合量る。計算する式とし て $n=\frac{(71)-\mathrm{Am}) \cdot 100}{30}(n \cdot$ テテフテンの含量 $\% 、 \mathrm{Am}$. 混合物のアニリン點) なる式が與へられたれども極端 な万場合、例へばチクローキサン（アニリン點 30)の みよりなろ時はナフテンの含量として $133.3 \%$ となる が如く一般的に流適合ざるしのなり、著者はn一ーキ サン、 $n$-ヘプタン、チクロヘキサン、メチールテクロ へキサン等名化學的に純粹なるもの古作り、各々のア ニリン點炛測定し是等の既知混合物のアニリン點より

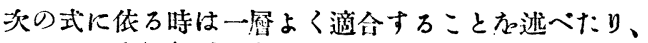
即 $5 n=\frac{(A-\mathrm{Am}) \cdot 100}{A-a}(A, a \cdots$ 雨成分のアニリン點 $\mathrm{Am} \cdot \cdots$ 混合物のアニリン點) 即ち上の式に依万時は 既知混合物の雨成分の含量とアニリン點ょり計算した 万含量とは略一致する事志示したり、然れどる全く未 知成分の湿合物に應用寸万時は正磪の值を得万事方得 $す ゙$ (A. Schaarschmid, H, Hofmeir u. Hans Leist, Zi:its. Angew. Chem., 193?, 43, 454) (山 田)

Boryslaw 原油察溜淺渣の水素添加 Boryslaw 原 油より $220^{\circ} \mathrm{C}$ 以下の溜出物か除きたる パラフィン合

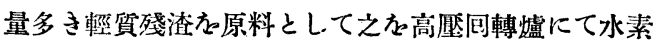
添加行ひたり、最初生成したろガソリン各问收し其 の殘渣龙数回水素添加吉行了時はガンリンの收量は $47.4 \%$ に達し油分及びアスファルトは $26.2 \%$ 、ガスと しての損失は $26.4 \%$ なり 、溫度及び反應時間はカ ソリン生成に及祄す最に大なる因子なり、又生成する
ガソリンは天然ガソリンに比较して蹬貿にして管香族 宸化水素の量も少く、Hつナフテンの量もアニリン點 の測定よりする時は幾分減少せること去せり（J. Ehriich u. Szayna, Petroleum, 193), 26, 1043)

(山田)

石油つコークス殘渣の測定に就て 色々の石油生生 物死蒸發したる場合のコークス殘渣の浿定は其の品質 秤價に必㛄なり、著者は色々の種類の減摩油に就て此 の試䱏を行ひたり、装置は Conradson 式のもの、即

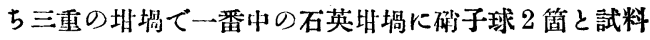
$1 \mathrm{~g}$ とな入れ下から大きな火て熱す、10 分內外て武 料より發生する瓦斯の燃え万程度に熱し、過熱せざ 漛に注意して 30 分後に消火して殘渣古科量す、著者 の用ひし試料は總て精製されしるのにて灰分は平均 $0.09 \%$ て外に上記のコークス殘渣に影警す万椂な無 機物々合まざろものなり、而して其のコークス殘渣量 は試料油の粘度の增すに從ひ墦加す万事方認め、又此 の法は同一試料に就て絽り返して試驗すれば平均值よ り大䯤 $6 \%$ 济隹れ万事が最高て、大抵の場合はょり少し

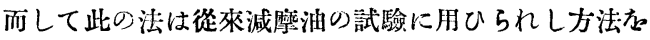
より喴格に行ふものなり (Berthold Rosenbaum, Chem. Ztg., 1939, 54, 89, 857) (小田)

ラングーンパラフィンの氣相分解蒸溜試驗 求も万

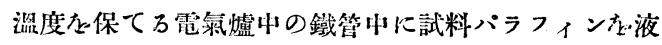
狀にて擜下さしめをこて分解せしめて後成生物方凝縮 器に導き減䐎の下に旋縮せしもろものなり、先う $450^{\circ}$ にて $10 \mathrm{~mm}$ の壓て試料态秒に 1 游の割にて湖下せ しむろ時はその $23.5 \%$ は固形の凝縮物となろ、此の ものは試料と殆んど變りなし、液狀生成物は全々無く 瓦斯は主に $\mathrm{H}_{2} 、 \mathrm{CH}_{4}$ よりなる、又最初に㠜縮する固 形物の分子量の增加してなる事から次の如く分子の端 がきれて、出來た不飽和のものが一部重合せるものな

$$
\mathrm{C}_{29} \mathrm{H}_{600}\left\{\begin{array}{c}
\mathrm{C}_{27} \mathrm{H}_{55}-\mathrm{CH}-\mathrm{CH}_{2} \rightarrow \\
\mathrm{H} \quad \mathrm{H} \\
\mathrm{C}_{27} \mathrm{H}_{55}-\mathrm{CH}=\mathrm{CH}_{2}+\mathrm{H}_{2} \\
\\
\mathrm{C}_{26} \mathrm{H}_{53}-\mathrm{CH}=\mathrm{CH}_{2}-\mathrm{CH}_{3} \rightarrow \\
\mathrm{H} \\
\mathrm{C}_{26} \mathrm{H}_{53}-\mathrm{CH}=\mathrm{CH}_{2}+\mathrm{CH}_{4}
\end{array}\right.
$$

り、次に溫度る $600^{\circ}$ にして $1 \mathrm{cmm}$ の是て 1 秒に 1

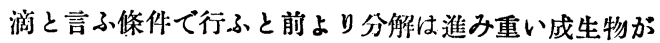
減り㜞以部分て增し液狀生成物 8 出來 $\mathrm{H}_{2} 、 \mathrm{CH}_{4}$ の發 生量も少くなり、より高級の瓦斯が出來、其の他の事 實より此の場合は前の樣な分解の他に 


$$
\begin{gathered}
\mathrm{C}_{26} \mathrm{H}_{53}-\mathrm{CH}-\mathrm{CH}-\mathrm{CH}_{2} \rightarrow \mathrm{C}_{27} \mathrm{H}_{56}+\mathrm{C}_{2} \mathrm{H}_{4}, \\
\mathrm{H} \quad \because \quad \mathrm{H} \\
\mathrm{C}_{26} \mathrm{H}_{53}-\mathrm{CH}-\mathrm{CH}-\mathrm{CH}_{2} \rightarrow \mathrm{C}_{27} \mathrm{H}_{54}+\mathrm{C}_{2} \mathrm{H}_{6} \\
\therefore \mathrm{H} \quad \mathrm{H} \quad \mathrm{H}
\end{gathered}
$$

の如き分解が起万ものと思は万、次に溫度か $606^{\circ}$, $10 \mathrm{~mm}$ の壓、 5 秒に 3 滴の條件て行ふと第二可目の 結果と殆んぞ差無し、次に $700^{\circ}, 30 \mathrm{~mm}, 2$ 秒に 1 游 の條件で行ふと結果沬前と大差ないが分子の切れ万所 が段々中央に移る傾向を示す、刃不館和の部分が著し く增す、次に此て場合に 1 秒 1 游にしても結果には 賏化無し、著者は上の賽驗結果か詳しくグラフに示し てるろが裂するに溫度危上げる程輕い部分が增加し、 其の不飽度 (息素價) 叴增し特に此の臭素價は輕い部 分に於て大となり又一つの分子が分解して出來万分子 の數る溫度と共に增加するてのなり (J. W. Heymans, J. Instit. Petrol. Techno., 1930, 16, 84, C61)

\section{(小田)}

\section{モーターベンゼンの硫酸試驗に就てさきにDr.}

Kaudela はモモターベンゼン或はベンチンの品質か 硫酸試驗によつて定めることる發表してるろが、此の 硫酸試驗の結果の良いもの必ずしも實際使用の際に放 んど殘渣虑殘さ奴とは限ら姑、故に著者は此の目的に 硫酸試驗上り寧万蒸發試驗 (Abdampf-Test) た行ふ べきであると提唱してわら、而して此の蒸發試驗に於 ては單にビーカーに入れて熱し蒸發させるとか又蒸溜 用フラスコれ用ひて大部分方蒸溜し其の殘渣㤂乾燥器 中にて軲して殘渣を科量す万等、其の方法如何により 可成りの異つた結果が出ろ、それで試驗法として嘪際 モーター內にて起ろ時に近い狀態て即ち熱をかけて空 氣厹通じながら蒸發せしもる法かとつてるる、試料に $200 \mathrm{cc}$ 名とり 2〜3 時間內に大部㤂登發さしめて後强 く熱して最後に固體の不揮發性の樹脂樣物質が殘万樣 にするるのなり、此の後の强く熱寸る時間の長短は殆 んど結果に影響せず、著者は色々の試料に就て此の試 驗炛行ひ同時に比重、沸點、硫酸試驗、臭素價等后測定 して๖ろ、此等の試驗結果によると脂肪族、芳香族は 一般に沸點の高〈なるほど残滥が大となり文ベンチン は一般にモーターベンゼンょり蒸發殘渣が大ておる、 又モーターベンゼンに於て完全に硫酸洗滌されたいの は一部分洗湺されだのより却つて此の蒸發殘渣が多 い故に高い費用と大なる損失とる犠牲にして完全に 硫酸洗洛各する事は殆んど無意味ておると稱してる
ろ、そしてヌ從來の硫酸試驗良廢して此の蒸發試驗方 行ふぺきておると顶いてるる (Friedrich Knöttner, Brenn. Chem., 1930, 11, 432) (小田)

浘合油に於ける粘度、引火黙の低下 異つけ粘度、 異つけ引火點の銅油方混合す万か又は鑛油に脂肺油を 混じても其の得られた混合油の粘度、引火點は其の成 分の其等の算術的平均より低くなろ、著者は之に對し て次の如實驗式を呈出してる乃

$$
\begin{aligned}
& V=[a . A+b . B-v \cdot A-B)] / 100 \\
& F=[a . A+b . B-f(A-B)] / 100
\end{aligned}
$$

$V . F$ は混合油の粘度、引火點であり $a . b$ は混合の百 分率て $A . B$ は(1)に於ては 2 成分の粘度を(2)に於 ては引火點态表してるる、v. $f$ は實驗的に定め万べき 係數ておろ、そして $A>B$ であろ、此等の式は其の 成分油の化學的構造には關係なく物理的の性質による ものて脂肪油店 1 成分にとつけ時にも使用出來万 (Dr. Erich Kadmer., Chem. Ztg., 1930, 54, 871)

(小田)

岸化水秦の分解蒸溜 多くの交献方引用して分解工 業を詳逃したるるのにして初禹なる工業的分解装置

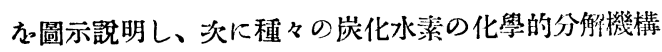
に就て諭迅し向觸媒の接觸的分解に就ても述へたり、 最後に常㟲に於け万分解賽驗の報告としてメッセル岩 油、パラフィン等か試料とし、觸媒としては活性宸素、 モリブデン酸、輕石、メタノール觸媒、鐵管、モネル 管等を使用したる場合に就て詳細なる記䤵な與へたり (E. Berl u. Rudolf Lind, Petro'tum, 1930, 26, 1027-1042, 1057-1070) (山 田)

ストレートランガス油及びサイタルガス油のクラッ キング價 タンク及びチェウブ式の小さき賽验装置に 依つてミドコンチネント原油より得られろガス油に就 て分解賽驗长行ひたるものにして次の如き結論死得た

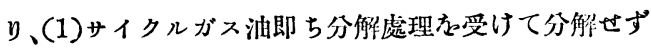
して殘りたろるのは分解處理方繰返すことに依つてが ソリンの生成量后減少す、實驗結果にてはストレート ランガス油は $24.3 \%$ ガンリンか與へ 4 回目のサイク ルガス油は $14.9 \%$ のガンリンか與へたり、(2)サイク 几か繰返すことに依つて生成燃料油對生成ガンリンの 比は增加す、（3）サイクル存繰返すことに依つて A. P. I. グラヴィテーを低下す、實驗結果にてはストレー トランガス油は 33.7 にして 4 回目のサイクルガス油 は 24.7 杂せり、(4)サイクルか繰返すことに依つて 沸點範圍か縮少す、(5)サイクルか繰返すことに依つて 化學的組成に變化な來けレしアンリン點炛低下す、實驗 
結果にてはストレートランのるのは 169 か示し 4 回の サイクルを受けろ時は 84 に低下寸 (H. Sydnor and A C. Patterson, Ind. Eng. Chem., 1930, 22, 1237) (山田)

プロパンよりカーポンプラックの䌘造 キャンネル プロセスに依らプロパンよりカーボンブラックの製造 に於けろサャンネルの高さ、キャンネルの潈度、パー セントコムバッション等の影皕に就て實驗したるるの なり、キャンネルの高さとカーボンブラックの生成量 との關係は次表の如し(他の賽驗條件は何れる同じ)

キャンネルの高さ(mm) $\quad 45 \quad 70 \quad 95 \quad 120$

Mcu ft より生成寸万量(lbs) 1.673 .001 .380 .65 又キャンネルの溫度が收量に及玨す影響は $410^{\circ} \mathrm{C}$, $516^{\circ} \mathrm{C}, 650^{\circ} \mathrm{C}$ の夫々に於て $3.46,3.00,0.47 \mathrm{lbs}$ にし てパーセントコムバッションの影響は 70 及び 400 の 場合に於ては夫タ 0.76 及び $0.47 \mathrm{lbs}$ なり、台キャン ネルが存在さざ万場合と存在する場合とは收量に於 て 1.65 及び $3.00 \mathrm{lbs}$ の如き相違を示せり (W. B. Plummer and T. P. Keller, In r. Eng. Chem., 1930, 22, 1209)

アスファルト含有量の測定 所帽アスファルトと科 するものの中に含まれろ純粹のアスファルト量方测定 する場合に使用す万溶劑が異れば其の結果る異ろ、著 者はェーテルとノルマルベンチンとる用ひて比較試驗 艻行ひエーテルの方が次の如き諸點に於てノルマルベ ンチンに優れる事方示せり、方法は $2 \mathrm{~g}$ のアスファル トか 150cc のフラスコ中にて 100cc の溶劑と共に一 晚放置し濾過すう方法であろがベンチンなれば其の沸 點、比重、表面張力等其の他種々の性貿に標潐方定め

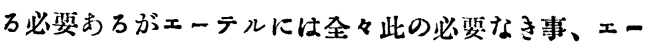

テルの表面張力の小なろ事、アスファルトの中には時 タオキシ脂肪酸があろがベンチンか用子と此物 6共に 溶けて不正磪の結果が出万事、エーテルは石炭タール 中の色々の物質に對し良き溶劑であ万事及びェーテル は安價で回收が容易でろがベンチンは之が出來ない 事等の諸點に於てェーテルの方が遙に良好なり (F.J. Nellensteyn u. N. M. Roodenburg, Chem. Zeit., 1930, 54, 819)

（小田）

\section{1，有機工業藥品及中間生成物}

\section{植物化缼上洼目すべきd，1-テトラヒドロパパヴリ}

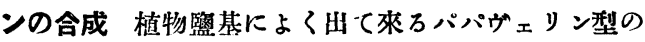
しのは1ーベンチル・インヒノリンより誘導出來ろが硃 Кイソヒ/リン核の 6 及伎 7、ベンチル核の 3 及ひ 4 の位置に七ドロキシル、メトキシル、メチレンヂオ キシ基を持つたものが多い、ロビンンン氏は之等の生 成に關してアミノ酸又は他のものから生じた $\alpha$-[3.4-

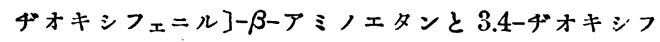
エニルアセタルデヒドが結合しホいのだと云ふ想像か した、著者等はメチルメーテルか用ひて之ね實驗的に 確かめようとした、即ちホモヴェラトリルアミン (1) とホモヴェラトルムアルデ七ド (II)各ェーテル溶液て 混ずれば容易に (III)なるシッフの祭基になるらしく、 之虎監酸で取扱一ば (III)は監酸に弱く、分解しHつ (II)は監酸で直ちに樹脂化するから困㐨であるけれど る $d, l$ ーテトラヒドロパパヴェリン(IV)が得られる、 收量 $8 \%$ 、(I) (II) は植物體內に存在すべきアミノ酸 等から容易に生じ得へきいのてあり植物體內ては (III) はそれ汪ど分解されないてあらうから之が實䧄 に行はれる反應であらう

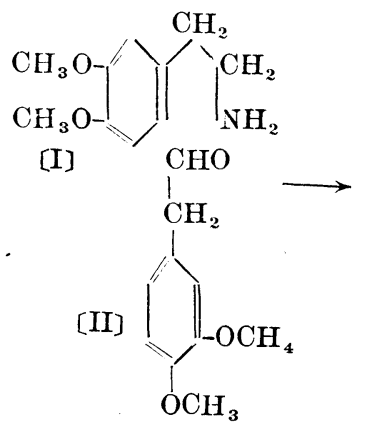

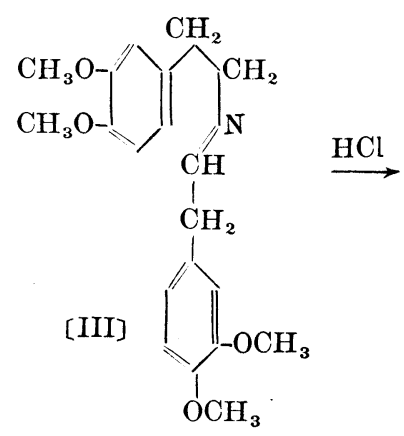


(E. Späth u. F. Berger, Ber., 1930, 63, 1098)

（宾戶圭）

4-カルボリン類の合成 4-カルポリン類か合成する には著者がさきにッルミンの合成に用ひた方法 (本誌, 抄錄, 昭 $5,33,126 \mathrm{~A}$ ) に依つ一目的方澾す万事が出 來ろ、即ちトリブタミンヌはその置換體か $N$ マアッィ ル化しキシロール中で五酸化燐と煮て環㤂閘ぢて5.6ヂ七ドロ-4ーカルボリンとなしパラヂウム黙と熱して 脫水素すれば好い、例人ば 3-n-プロピルー4-カルボリ ンは次の如くして生成する<smiles>CCCC(=O)NCc1c[nH]c2ccccc12</smiles>

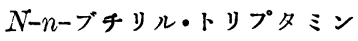

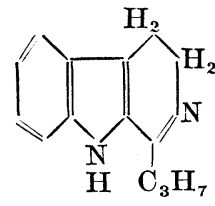

5.6-ヂヒドロー4カルボリン

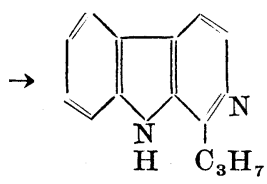

3.nープロピル -4 カルボりン
この方法で多くの誘導體が合成出來乃が著者等がかつ てインヒノリンを合成した時に 1 の位置に置換基る持 たないものが非來にくかつた樣にこの場合も4-カル ボリンは $N$ フォフルミルトリプタミンからは容易に山 來ない、此の場合にはトリプタミンとフォルムアルデ ヒドからシツフの監基、テトラヒドレー4ーカルボリンね 經て合成寸ろ (E Späth u. E. Lederer, Ber., 1930, 63, 2102)

(突戶圭)

モノクロール醋酸の製法 $200 \mathrm{~kg}$ の水醋酸に $1 \mathrm{~kg}$ の沃度、 $5 \mathrm{~kg}$ の五嚂化燐、 $5 \mathrm{~kg}$ の赤燐长加へ $100^{\circ} に$

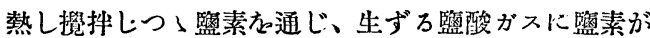
混じて來るに至つて止め燐店濾别し向 $25 \mathrm{~kg}$ の水醧 酸え加人てモノクロール醋酸え結晶させる、收量は $220 \mathrm{~kg}$ (Horst Bri:ckner, D. R P., 506,280)

(突戶来)

マレイン酸無水物のポリェンへの加成 ヂェルス、 アルダー兩氏に依るヂェンとマレイン酸艁水物との結 合は合成化學上に廣い雔用かもたらしたばかりでなく 構造決定上にも多く利用されてるろ、故に此の反應が カロチノイドに對して成立すろか否かは理椧及び實際 上重要なことである、著者等が試みた所に依れば立派
に反應し又生成物の結晶も取れたののであろが多くの異 性體が出來乃のてその構造か決定するには至らない、 故に先づ合成したヂフェニルボリェンに就て此の研究 そ進めた、スチルベンは二重結合な 1 個しか持つてょ ないがマレイン酸無水物と 1:1 の制合に結合すろ、時 に依り 1:2 の割合に結合すらものもあろが之等に就 ては後に報告する

1.4-ヂフェニルブタヂェンとはヂェルズ氏等の㥞な 結合かするが下の樣な異性艠ね生じろ樣に思はれる

I.<smiles>O=C1OC(=O)C2CCC1C=CC2c1ccccc1</smiles>

II.

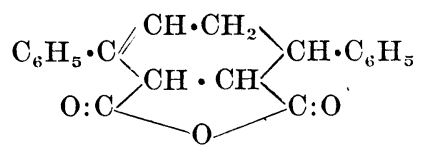

1.6ーヂフェニルへキサトリェンは 1.4 の位置に一分 子のマレイン酸無水物を結合するが（生成物を無水水 酸化バリウム及びゼレンと堂溜すれば $\mathrm{C}_{6} \mathrm{H}_{5} \cdot \mathrm{CH}=$ $\mathrm{CH} \cdot \mathrm{C}_{6} \mathrm{H}_{4} \cdot \mathrm{C}_{6} \mathrm{H}_{5}-(p)$ が得られろ) 此の場合も I, II の柡にチクルへキセン環内の二重結合の位置で異性骴 があるらしい

1.8ーヂフェニルオクタテトラェンは二分子のマレイ ン酸無水物方結合寸るがやはり異性能がある、モノ加

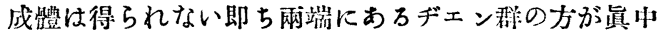
のものょりも反應し易いことな示してるろ、加成體よ リクアテルフェニルが得られろが一部分㨁線的構造で ないものもあろらしい

1.10-ヂフェニルデカペンタェンは 1.4-及び 7.10-の 位置に加成する、以下テトラデカへプタェンまで賽驗 方行つげが之等よりポリエンは常に六源子環方作万樣 に作用し雨端のメチン基が易反應性であろから端のヂ エン碓から結合して行くこと起知つた、マイレン酸無 水物の加成は先づ分子化合物の生成（着色する）に始 まりその色がさめて第一次加成體が安定になり、更に その $2 、 3$ の位置にあろ二重結合がフェニル基或は他 の二重結合と共扼の形になつて安定して行くものと考 一られろ(R. Kuhn u. T. Wagner-Jauregg, Ber., 1939, 63, 2662)

（贵巨圭）

リコピン及びカロチンの構造 さきに著者等はカロ チンの部分的構迠式を提出し（本誌, 抄錄, 昭 5,33 , 116A）それがリコビンの環閉鑽に依り生成し得べき こと老(本誌, 抄錄、昭 $5,33,19 \mathrm{JA}$ )还ぺげがカロチ ンの第 2 の環の部分はまだ不明であつた、然るに之等 
の物質は左右對稱り構造る有するものと考人万時は多 くの事賽るうまく筧明し得られるから次の樣な式が想 像せられる<smiles>C=CC=CC=C(C)CCC=C(C)C</smiles>

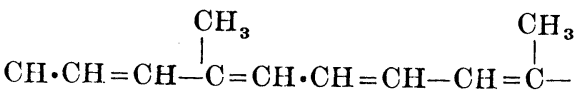
$\mathrm{CH}=\mathrm{CH} \cdot \mathrm{CH}=\stackrel{\mathrm{CH}_{3}}{\mathrm{C}}-\mathrm{CH}=\mathrm{CH} \cdot \mathrm{CH}=$<smiles>CCCC=C(C)C</smiles>
$\downarrow$<smiles>C=CC=CC=C(C)C=CC1=C(C)CCCC1(C)C</smiles><smiles>CC=CC=C(C)C=CC=C(C)C</smiles><smiles>C=CC1=C(C)CCC1(C)C</smiles>

分子の山央でィップレン基の結合の順が逆になつてる ろのはフィトールの如きものの二分子が結合して出來 ホものと考へれば好い、同椾に考へればスクアレンは 二分子のファルネッ゙ール占出來たものであつて次の 樣な構造式が想像される

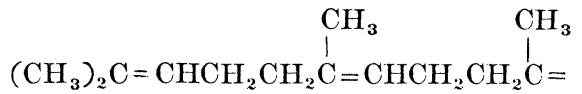
$\mathrm{CH}-\mathrm{CH}_{2} \mathrm{CH}_{2}-\mathrm{CH}=\stackrel{\mathrm{CH}_{3}}{\mathrm{CCH}_{2} \mathrm{CH}_{2} \mathrm{CH}=}$.

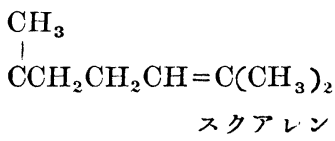

(P. Karrer, A. Helfenstein, H. Wehrli und A. Wettstein, Helv., 1930, 13, 1084）（突戶圭)
不飽和着色脂眆酸の合成 著者等に依れば脂肪族宸 化水素が色方持つためには 5,6 個の二重結合が並ん で共扼にある方裂し又カルホキシル基が共䡉にある時 は約 1.5 個の二重結合に相當した働きかするのであ ろ、寸ろとクロトン酸 (I)メジルピン酸 (II)のヴィニ レン同族能ではオクタトリェン酸 (III)とデカデトラ エン酸（IV)の間にならなければ着色して來ない筈て あろ、實際之等后合成して見ろにその通りであつて (III)は厚い尿でかすかに黃、(IV)は濃黃色である、 又前の經驗と同じく監にすれば色がなくなる
(I ) $\mathrm{CH}_{3} \cdot \mathrm{CH}=\mathrm{CH}-\mathrm{COOH}$
(II) $\mathrm{CH}_{3} \cdot[\mathrm{CH}=\mathrm{CH}]_{2} \cdot \mathrm{COOH}$
(III) $\mathrm{CH}_{3} \cdot[\mathrm{CH}=\mathrm{CH}]_{3} \cdot \mathrm{COOH}$
(1V) $\mathrm{CH}_{3} \cdot[\mathrm{CH}=\mathrm{CH}]_{4} \cdot \mathrm{COOH}$

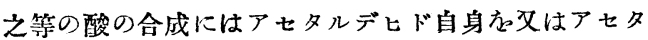
ルデ七ドとクロトンアルデ七ト $\left(I^{\prime}\right)$ と第二級アミン 例へばピペリヂンの存在の下に縮合させへキサヂェナ ル(II')皮びオクタトリェナル( $\left.\mathrm{III}^{\prime}\right)$ 得、之等かピ ヂン山でマロン酸と働らかせて (III)及び (IV)店得 た、(II')や(III')のアッィンはボリェンの如き呈色反 應をなしよく結晶すろから識别に好い、(III)、(IV) の臭素消費量は理論數より遙に少く又臭化物は單一な ものでない、(III)、(IV)の二重結合はヂフェニルポリ ェンの場合と同じく皆トランスの位置にあるらしい、 動、植物能內の第二酸及び第三級アミンが上述のアル デ七ド縮合に接觸的作用かなすか及び之等のアルデ七 ド及び酸がどんな生物學的作用かするか心研究中であ ろ (R. Kuhn u. M. Hoffer, Ber., 193), 63, 216ł)

(宾戶圭)

ヂクロールアセチレンに就て 豫め熔融、脫水して 固化點灰 $260^{\circ}$ とした粒狀 $\mathrm{KOH}$ 上に $133^{\circ}$ にてト リクロールエチレンの蒸氣か通ずれば $65 \%$ の收量に てダクロールアセチレンな生ず、空氣中に出でたろ氣 泡は爆發して多量の煤死生ず、(水老充填液として使用 したる場合なり)ェーテルに5ー10\%溶したるるの は酸素瓦斯龙通ずろも徐々に自働酸化さらろろに過ぎ ず、四監化ェタン溶液の場合は之に反し極めて容に易 酸化さらろ、デクロールア七チレンは無色、易動性の 液䭪にて沸點は $29^{\circ} 、(743 \mathrm{~mm})$ (補正)ヂクロールアセ チレンの四監化炭素溶液に同じく臭素の四鹽化炭素か 加ふればヂブロシド ${ }_{\mathrm{Br}}^{\mathrm{Cl}} \backslash \mathrm{C}: \mathrm{C}{ }_{\mathrm{Br}}^{\mathrm{Cl}}$ か生ず沸點 58.5 $59 .^{\circ} 5 、(13 \mathrm{~mm})$ 融點 $4 .^{\circ} 9$ 、(補正)エーテル溶液にて徐 々に沃素添加热行へばヂョーヂド（融點 $70^{\circ}$ ) 生ず 
(E. Otto, W. Ottemeyer u. K. Packendorff, Ber., 193), 63, 1941)

(宇 野)

化アルミニウムに依るプロム化ナフタリンの㙛 位 監化アルミニウムの存在に於て進行す万反應は置 換基の轉位か起寸笘構造決定には使用し得す゚、例人ば $\alpha$ ークロル及び $\propto$ ーブロムナフタリンは $\mathrm{AlCl}_{3}$ と少し く加溫せば $\beta$ に轉位す、 $\mathrm{C}_{10}$-二置換體の相互の位 置決定に參考物質として用ひらろろヂハロゲンナフタ リンの $\mathrm{AlCl}_{3}$ に依ろ轉位は文献になき篇著者は此の 研究な行へり、1・2-ヂブロムナフタリンはナフタリン

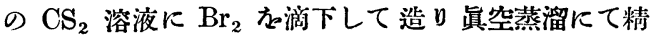
製し酒精より再結晶せろものは融點 $68^{\circ} 、$ 此の $30 \mathrm{~g}$

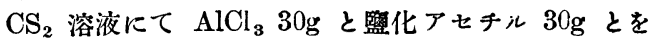
加人て加熱し 24 時間放置後再び加熱して反應か完結 して得たろ生成物は 1.4 ダプロム化合物(瀜點 $83^{\circ}$ ) とアセト 1.2 ヂブロム化合體 $\left(146^{\circ}\right)$ なり、又 1.2

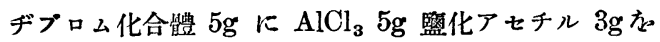
$\mathrm{CS}_{2}$ 溶液に常溫にて加一加熱して反應か完結せしめ場 合には融點 $131^{\circ}$ の 15 ヂブロム化合暟か得、又 1.2 化合體 $20 \mathrm{~g}$ を $\mathrm{CS}_{2}$ 溶液にて $50 \mathrm{~g}$ の $\mathrm{AlCl}_{3}$ 方加二沸 騰時 8 時間乾燥鹽酸瓦斯を通ずれば 2.6 化合體を黃 金黃色板狀結晶として又同時に 1.5 化合體をも生成す (H. Lohfert, Ber., 1930, 63, 1939) （宇 野)

水銀原子を含める異環㖣の生成に就て オルトヂブ ロムペンゾールにナトリウムアマルガムを作用せしむ れば $\quad \mathrm{C}_{6} \mathrm{H}_{4} \begin{aligned} & \mathrm{Br}+\mathrm{Na} \\ & \mathrm{Br}\end{aligned} \mathrm{Ng}_{\mathrm{Hg}}^{\mathrm{Hg}} \begin{aligned} & \mathrm{Na}+\mathrm{Br} \\ & \mathrm{Na}\end{aligned} \mathrm{C}_{6} \mathrm{H}_{4}$

の反應式に從つて
(I)

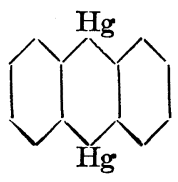

(II)<smiles>[CH]1CC2CCCC1C2</smiles>

り式の何れかにて表はし得乃組成の生成物な得、300 にても熔蛚さざろ結晶性粉末にして(I)、(II)の何れに 相當するかか決定する签に沸脸醋酸にて處理して得た 万分解生成物虏研究さしに、Bis-acetoxymercuribenzol $\mathrm{C}_{6} \mathrm{H}_{4} \backslash_{\mathrm{Hg} \cdot \mathrm{O} \cdot \mathrm{OC} \cdot \mathrm{CH}_{3}} \mathrm{Hg} \cdot \mathrm{O} \cdot \mathrm{OC} \cdot \mathrm{CH}_{3}$ 相當する組成なる も此の物睤は未知なっ隽是店 KI-I 溶液にて處理し て沃素化命物に繁へしに既知のオルトヂョードベンッ゙ 一ルな得げるに依り、醋酸に依る分解心。

$$
\begin{aligned}
& \mathrm{C}_{6} \mathrm{H}_{4}\left\langle\mathrm{Hg}_{\mathrm{Hg}}^{\mathrm{Hg}} \mathrm{C}_{6} \mathrm{H}_{4} \rightarrow\right. \\
& \mathrm{C}_{6} \mathrm{H}_{4} \searrow_{\mathrm{Hg} \cdot \mathrm{O} \cdot \mathrm{OC} \cdot \mathrm{CH}_{3}}{ }_{\mathrm{Hg} \cdot \mathrm{O} \cdot \mathrm{OC} \cdot \mathrm{CH}^{3}}+\mathrm{C}_{6} \mathrm{H}_{6}
\end{aligned}
$$

にて表はし得、從つて原物㑭の構喈式け（I)に相當す (L. Vecchiotti, Ber., 1930, 63, 2275)(宇 野)

-ピコリンのピペコリンヘの接触的摆元 さきに Zelinsky と Borissow は白金黑方付けし石綿上に $150^{\circ}$ にてビリヂンと水秦とな通ずれば定量的にピパ リヂンか生ずる事か知りしが今著者汁同一條件に於て 人ービ コンの還元か研究せり、觸媒として $29 \%$ パラ ヂウム石綿か使用し $160^{\circ}$ にて 10 湖/分の速度にて 1 司通ずれば $n_{16}=1.4631$ (ピコリン $n_{16}=1.5034$ ）と なり、2 包通ずれば $n_{16}=1.4520$ となり、是な分溜し

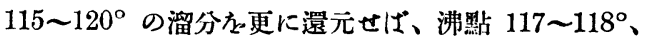
$(747 \mathrm{~mm}) 、 n_{16}=1.4492$ 、分子屈析 31.47 にしてピぺ コリンと一致す(P. Borissow, Ber., 1930, 63, 2278)

(宇 野)

フェナンスレンの精㹕 著者は從來提出されたる方 法を批評し Sandguist の方法死基礎としてアンスラ センを完全にアンスラキノンに酸化せしめフェナンス レンは殆んど作用え受けしめざろ精製法る提案せり、 先づ粗製フェナンスレンか 2 倍量の $95 \%$ 酒精に溶し $15^{\circ} \mathrm{C}$ に冷却して㴔過すれば $80 \%$ の收量にて融點 $105 \sim 110^{\circ} \mathrm{C}$ の灰色結晶方得、次に之方 5 倍量の酒精 に溶し 1/8 量の濃碩酸方加へて 1.5 時間者沸せしめ、 赤色物分滩し來れば熱閒に濾過す、冷後 80〜 93\% 收量にて融點 3 3 $96^{\circ} \mathrm{C}$ の大なろ赤色結晶索生ず、次 で之ね常厴にて蒸溜すればフェナンスレンは黃色の油 となりて溜出する故之な水中に觬拌しつい捕集すれば 淡黃色の結晶となる、此の結晶な乾燥し更に 2 倍量の 酒精より再結晶せしもれば原料粗製つェナンスレンの 30〜40 の收量にて融點 $99 \sim 99.5^{\circ} \mathrm{C}$ の純粹なろ結晶 な得、本操作に於て溶媒の $80 \%$ 以上る司收し得とせ y (F. I. Cohen \& U. Cormier, J. A.C.S, 1930, 52, 4363)

(折 戶)

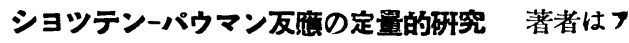
ルコールとしてメチルー、ェチルー、アリルー、ベンヂルー、 アルコール、グリセリン、䈍糖及びフェノールを、酸 盆化物としてアセチルー、゙ンゾイルー、ベンゼンスルフ ホークロライドか用ひてェステル生成の收量に就て研 究せり、アルコールはェチルー、アリルー、ヘンヂルー、メ チルーアルコール、グリセリン、蔗糖、フェノールの順

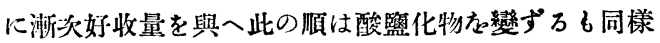
なり、又酸監化物はアセチルー、(無水醋酸)ベンゼンス ルフォー、ベンゾイルークロライドの順に溸次好收量た 與人此の順はアルコールね變ずるも同樣なり、而して 著者はェステルの好收量か得ろには次の注意か必耎と 
せり（1）泪度は可及的低〈保つ事、（2）酸殈化物は發 熱を避く万䉆少量宛加ふ万事、(3) 苛性ソーダより苛 性カリ九用ふ万事、（4)アルカリは可及的濃厚なる事、 (5) 反應終了後瞼化九避く万签ェステル注可及的早く 分離す万事、(6) 過剩の酸監化物々用ふ万事、著者は

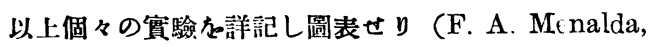
Rec. Trav. Chim Pays-Bas, 1930, 49, 967)

\section{(折 戶)}

酒精の脫水に監化カルシウムの䈍用 著者は $100 \mathrm{cc}$ の $81.3 \%$ 酒精に 2 g の監化カルジム方加へ 8 球 附ヤング氏精溜管方附し 1 分間に 150 滴の速度にて 蒸溜したるに $95.0 \%$ 酒精を $77.7 \%$ 、殘液な $5.7 \%$

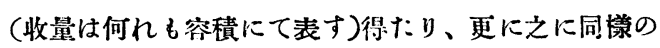

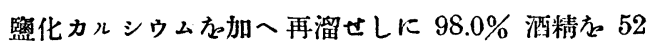

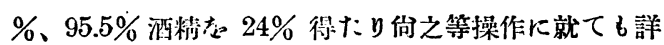
記しおり、便利にして正磪なる酒精濃度の試驗法とし て著者は次の種々の溶媒 $5 \mathrm{cc}$ と 1 游の酒精との混和 ね提出し居れり、即ちヶロシン及び石油は夫々 99.25 \%文び $98.3 \%$ 酒精と混和す、キシロールは 1 消に ては 97.4\% 酒精と僅かなる黄りる生ずるる振盪すれ ば澄明となろ、97.2\% 酒精とは1〜2游にては漸次消

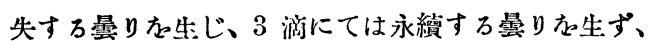
$97.1 \%$ 酒精とは 2 滳にて 永續性最りる生す、此のキ シロールによろ試驗法は温度の影響大なれば 15一 $19^{\circ} \mathrm{C}$ に於て施行す万の必项ありとせり（K. B Edwards \& R. Lacey, J. S. C. I., 1930, 49, 422T)

(折 戸)

\section{2、染料、染法及染織}

フルフラールより生成せらる 新杂料に就て 著者

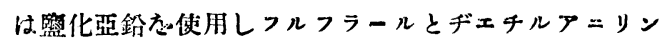
と走縮合しマラカイトグリーン製法に則りて一新染料 々合成し得たり、斯くして生成せらろい新染料はテト ラェチルダアミド・ダフェニル・フリールメタン暨酸監 の化學構造を有し監化严鉛の複㧞として晶出し理論上 の得量に對し得零 $17.2 \%$ 吕示さり、新染料を以て絹 を染色したるに洗滌に對し堅暒なるも日光に對する堅 牢度はマラカイドワリーンに比し稍遜色あり（S. A. Mahood and H. F. Aldrich, J. Am. Chem. Soc., 193), 52, 4477)

(上. 田)

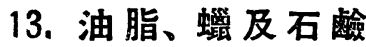

固嗑脂眆酸 本法はトイッテェル氏の鉛監アルコー 几法々少しく改めて油脂小の固能脂肪酸か定量寸万る
のなり、試料は固體酸 1〜1.5g ね含むゃj(但し全體 として $6 \mathrm{~g}$ 迄) 30 Ccc 容のェルェンマイャーフラスコ に科取し酒精加里液 $49 \mathrm{cc}$ 方加人て畧化し、後水醋酸

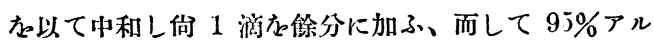
コールな以て全容店 $150 \mathrm{cc}$ となし别に酷酸鉛 $5 \mathrm{~g}$ をア

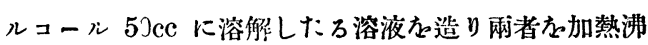
騰せしめつつ混合す、然万後放冷して空溫となれば $15^{\mathrm{C}} \mathrm{C}$ の水函中に入れ一夜放置す、後滤過し、沈澱は 95 \%アルコールにて濾液が水か添加寸っも洞濁せざるに 到乃迄洗滌し、沈股は更にフラスコに入れアルコール $100 \mathrm{cc}$ 及び水䤊酸 $0.5 \mathrm{ce}$ と共に加熱沸騰せしも、濾過 後沈澱は前同樣に洗㹋す、斯くて沈澱なェーテルね以 て 500cc 签分液漏斗に移し $1: 1$ 監酸 $25 \mathrm{cc}$ を加一て 振笽し、エーテル層は監酸の無くなる迄水々以て洗滌 した:万後無水芒确 6〜 $7 \mathrm{~g}$ 名加へて脱水し、ェーテル 溶液は重量既知の $200 \mathrm{cc}$ 容エルンンマイヤーフラス コに移しェーテルね蒸溜し去り更に炭酸瓦斯氣流中に $110^{\circ} \mathrm{C}$ に加熱して恒量ならしめ固䯠酸の 量る知万 (Walter F. Baugmin and George S. Jamieson, Oil and Fat Ind, 193 ', 7, 331; C. A., 1930, 24, 5519)

ネルヴオン酸(Nervonic acia)の合成 Klenk 氏 は牛及び人の腦より融點 $41^{\circ} \mathrm{C}$ の不飽和酸っ 檢出し $\mathrm{C}_{24} \mathrm{H}_{46} \mathrm{O}_{2}$ なる化學式方與一更に酸化え行ひその構 造け次の如くなりとせり

$$
\mathrm{CH}_{3} \cdot\left(\mathrm{CH}_{2}\right)_{7}-\mathrm{CH}=\mathrm{CH}-\left(\mathrm{CH}_{2}\right)_{13}-\mathrm{COOH}
$$
佾之ねェライヂン化すれば融點は $61^{\circ} \mathrm{C}$ となると即 cis 型なり、ネルヴオン酸は辻本氏が鯨油より分離せ ろセラコレイン酸に一致せり、著者等はェルシン酸メ チルエステルね用ひネルヴオン酸の合成か企てたり、 即ちェルミン酸メチルェステルね無水正ブチレアルコ 一ル及び金屬ナトリゥムる以て還元してェルシルアル エール (沸點 $230 \sim 205^{\circ} \mathrm{C}, 1 \mathrm{~mm}$; 融點 $34 \sim 35^{\circ} \mathrm{C}$ ) に變じ更に無水トルェン中に於て三臭化燐々以てェル シルブロマイド（沸點 $203 〜 297^{\circ} \mathrm{C}, 1 \mathrm{~mm}$ ）となし之

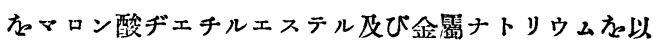
て處理しェルシルマロン酸ェステル(沸點 $203 \sim 207^{\circ}$,

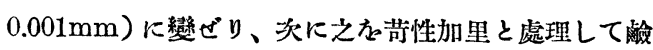
化、分解し、得たっ酸かェーテルに依り探りェーテル る去りたろ後減是蒸溜せり、溜时せる酸は混合物なる 支以て無水アルコールょり分别結晶し先う融點 $61^{\circ} \mathrm{C}$ の trans 型ネルヴオン酸か得、更に滤液より融點 39 - 39.5C の cis 型ネルヴオン酸を得たり、之等々 酸化白金觸媒㤂以て水素化したるに融點 $83 \sim 84^{\circ} \mathrm{C}$ の 
正テトラコサン酸 $\mathrm{C}_{24} \mathrm{H}_{48} \mathrm{O}_{2}$ な得だり、正テトラ コサン酸のェチルェステルは白色板狀結晶にて蛚點 $55 ー 55^{\cap} \mathrm{C}$ なり

以上合成の反應式次の如し

$$
\begin{aligned}
& \mathrm{CH}_{3} \cdot\left(\mathrm{CH}_{2}\right)_{7} \mathrm{CH}=\mathrm{CH} \cdot\left(\mathrm{CH}_{2}\right)_{11} \cdot \mathrm{COOCH}_{3} \rightarrow \\
& \mathrm{CH}_{3} \cdot\left(\mathrm{CH}_{2}\right)_{7} \cdot \mathrm{CH}=\mathrm{CH} \cdot\left(\mathrm{CH}_{2}\right)_{11} \cdot \mathrm{CH}_{2}-\mathrm{OH} \rightarrow \\
& \mathrm{CH}_{3} \cdot\left(\mathrm{CH}_{2}\right)_{7} \cdot \mathrm{CH}=\mathrm{CH} \cdot\left(\mathrm{CH}_{2}\right)_{11} \cdot \mathrm{CH}_{2} \mathrm{Br} \\
& +\mathrm{CH}_{2}\left(\mathrm{COOC}_{2} \mathrm{H}_{5}\right)_{2} \\
& \mathrm{CH}_{3} \cdot\left(\mathrm{CH}_{2}\right)_{7} \cdot \mathrm{CH}=\mathrm{CH} \cdot\left(\mathrm{CH}_{2}\right)_{11} \cdot \mathrm{CH}_{2} \cdot \mathrm{CH} \\
& \quad\left(\mathrm{COOC}_{2} \mathrm{H}_{5}\right)_{2} \rightarrow \mathrm{CH}_{3} \cdot\left(\mathrm{CH}_{2}\right)_{7} \cdot \mathrm{CH}_{2} \mathrm{CH} \cdot \\
& \left(\mathrm{CH}_{2}\right)_{11} \mathrm{CH}_{2}-\mathrm{CH}_{2} \cdot \mathrm{COOH}
\end{aligned}
$$

(J. B. Hale, W. H. Lycan and R. Adams, $J$. Amer. Chem. Foc., 1930, 52, 4536)

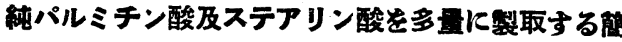

單ねる方法 Stillingia 脂はバルミチン酸の多量及オ レイン酸の僅量より成万な以て之る原料としオートク レーヴにて分解し混合脂肪酸を製し之よりオレイン酸

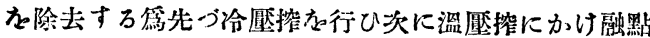
$60.8^{\circ}$, 沃素價 2.42 , 酸偩 218.2 の酸方得たり、更に アルコールね混じ泠壓搾な行ひたる後溫壓搾し、アル コールを完全に除去し 純䊀なるハハルミチン酸を得た り、融點 $62.6^{\circ}\left(62.6^{\circ}\right)$, 沃素價 $0.45(0.00)$, 酸價 219.2 (219.2)

ステアリン酸方製するには Bassia Parkii 種子よ り得万固體酸方原料としパルミチン酸の場合と同樣に 行ひたり、融點 $69.7^{\circ}\left(69.7^{\circ}\right)$ 、沃素價 $0.41(0.00)$, 酸 價 $197.5(197.5)$ 、不畧化物 $0.10 \%$ ( 0.00 )、纷固體酸 少きオリーブ油(Nizzaer) 水素化し之よりステアリ ン酸死製す万法在も記せり(Hugo Dubovitz, Chom. Zig., 1930, 54, 814)

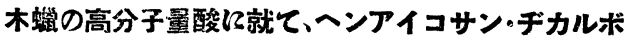

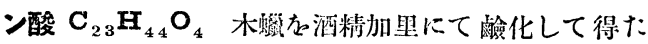
乃脂肪酸混合物な0.2mm 壓下にて蒸溜し $200^{\circ} \mathrm{C}$ 迄に $77 \%$ 肪脂酸溜出物（主とし.てパルミチン酸）方得た り、䔲溜殘渣はメチルェステルに變じ分别結晶を行ひ 融點 $1 ! 8 \sim 119^{\circ} \mathrm{C}$ の酸てメチルェステル混合物として 得、更にその溶液より融點 $108 \sim 119^{\circ} \mathrm{C}$ の酸か混合メ チルェステルとして得たり、前者は減塺蒸溜か繰返し 瞼化したっ後再びェステル化して再結晶方行ひたり、 斯くてアイコサジ・カルボン酸 $\mathrm{C}_{21} \mathrm{H}_{42} \mathrm{O}_{2}$ 融點 $74^{\circ} \mathrm{C}$ 及びヘンアイコサン、ヂカルボン酸 $\mathrm{C}_{23} \mathrm{H}_{44} \mathrm{O}_{4}$ 融點 $127.5^{\circ} \mathrm{C}$ 死得たり、ヘンアイコサン、ヂカルボン酸は 有機溶剂に對し室溫にて約 $1 / 1000$ 溶解し、熱アセト ンには約 $1 / 6$ ), 熱クロロフォルムには $1 / 30$ ベンゾール.
及びアルコールには更に多く溶解す、誘導體の融點次 の如し、ヂメチルェステル $\mathrm{C}_{25} \mathrm{H}_{48} \mathrm{O}_{4} 70.8 \mathrm{C}$ ，モ， メチルェステル $\mathrm{C}_{24} \mathrm{H}_{46} \mathrm{O}_{4} 87^{\circ} \mathrm{C}$, צ゙ェルェステル $\mathrm{C}_{27} \mathrm{H}_{48} \mathrm{O}_{4} 61.5^{\circ} \mathrm{C}$, モノメチルエステル $\mathrm{C}_{25} \mathrm{H}_{52} \mathrm{O}_{4}$ $83.3^{\circ} \mathrm{C}$

濾液より得げ融點 $108 \sim 1 \overline{1} 9^{\circ} \mathrm{C}$ の酸より分别結晶 に依り融點 $121.5^{\circ} \mathrm{C}$ のヂカルボン酸か得たり、恐ら く不純なろ 日本酸なろへし、その誘導唱の融點次の 如し、ヂメチルェステル $60^{\circ} \mathrm{C}$ ，ヂェチルェステル $\mathrm{C}_{25} \mathrm{H}_{48} \mathrm{O}_{4} 50.2 \mathrm{C}$

份合成日本酸と該酸との混融點 $118.2^{\circ} \mathrm{C}$ ホり

(Bonifaz Flaschenträger und Friedlich Hall, Chem.

Zentralb., 1930, Bd. II, 2761)

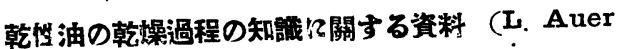
の氣䀧凝固說に䧕て）著者の亞麻仁油、同ワニス其の 他計 16 種の乾性油及び其の塗料各确子板に塗布し空 氣中、稀薄空氣中及び稀薄跮素瓦斯中に放置せる結果 次の如し、(1) 乾性油の塗料は稀薄空氣小に於ては豫 ぬ存在す万酸素量以上に重量增加せず、寧万少し、(2) 酸素の存在せさろ空素中に於ては乾怺油の塗料は乾燥 せず、(3) 空氣稀薄容器中に於ては乾燥中桼力增加せ す、悹ろ減少す、以上の結果 Auer の假説は是認せ られず(H Schmalfuss \& H. Werner, Kol. Zeits., $1929,49,323)$

(小倉)

亞麻仁油の六急化物俉測定 著者は六臭化物價測定 に際し冷却劑として固體岸酸（ドライアイス）を使用 せり、次の方法各行ひ好結果か得けり、即ち最高 $1 \mathrm{~g}$ の亞麻仁油脂肪酸を保溫フラスコ容器に科取しメーテ ルにて稀釋しドライアイスね投じて冷却し臭化す、次 に2簡の孔のあ万栓かなし水流水ンプに接續せる确子 管㤂液面近了迄插入し他の孔に監化カルシウム塔及び 冷却せるU字管に連結せ万确子管各扱入す、斯くし

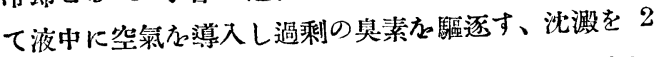
時問㙰置後滤過し、冷却さろェーテルにて洗滌す、 $0.2 \mathrm{~g}$ の脂肪酸にても測定し得れど此の際は損失な゙うく篇亲 臭化物にて飽和さるェーテルね使用す、著者は本法に

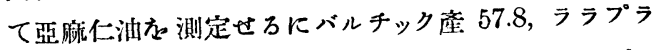
タ產 50.5 なり (F. Fritz, Chom. Ztg., 1930, 54, $383)$

(小 倉)

チクロプタン系に於ける環狀闌鎖 (II) $\alpha, \alpha^{\prime}$-ヂブ ロモアヂピン酸エステルの環狀化 是に Fuson 及び Kao 雨氏 (J. Amer. Chem. Soc., 1929, 51, 1536) は $\alpha, \alpha^{\prime}$ ーヂブロモアヂピン酸ヂェチルェステル（I）か 無水アルコール中にてシアン化ナトリウムと處理し 
1-シアノチクロブタン-1, 2・ヂカルポン酸ヂェチルェ ステル (II)ね得だり

$$
\begin{aligned}
& \mathrm{CH}_{2}-\mathrm{CHBr}-\mathrm{COOC}_{2} \mathrm{H}_{5} \stackrel{\mathrm{NaCN}}{\longrightarrow} \\
& \mathrm{CH}_{2}-\mathrm{CHBr}-\mathrm{COOC}_{2} \mathrm{H}_{5} \\
& \mathrm{CH}_{2}-\mathrm{CH}-\mathrm{COOC}_{2} \mathrm{H}_{5} \\
& \mathrm{CH}_{2}-\mathrm{C}(\mathrm{CN})-\mathrm{COOC}_{2} \mathrm{H}_{5}
\end{aligned}
$$

著者等は之と全く同樣にして $\beta$-メチルー $\alpha, \alpha$-ヂプ ロモアヂピン酸ヂェチルェステル (III) か以て實驗せ り、即ち (III) $20 \mathrm{~g}$ 各無水アルコール 15ce に溶解し 之に粉末シアン化ナトリウム $8 \mathrm{~g}$ ね加へ蒸氣浴上にて 24 時間加熱したる後冷却し無機物か滤别し、溶劑々 驅逐して 3-メチル-1-(或は 2) シアノー1,2-チクロプ タンヂカルホン酸ヂェチルェステル（IV)长得たり、 沸點 $140 \sim 143^{\circ}(3 \mathrm{~mm}), d_{4}^{22} 1.08854, n_{D}^{21} 1.44735$ 收量 8g、(63\%) 之多 Perkin 氏の法 (J. Chem. Soc., $1894,65,580) に$ 依り水酸化バリウムの溫溶液か以て 畧化しメチルチクロブタントリカルボン酸 $(\mathrm{V})$ 得た り、收量は理諭數の $67 \%$ 、、反應次の如し

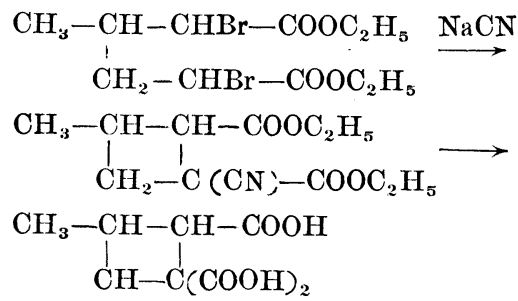

份ヂブロモアヂピン酸エステルとしてヂフェニルー 及ヂー ロモアヂピン酸のヂフェニルェステルはアヂピン酸ね チオニルクロライドと處理してアダビルクロライドと なし之ね臭素及び三臭化燐に依りて $\alpha, \alpha^{\prime}$ ヂブロモア ヂピルクロラィド (VI) に嚾じ次にフェノールな加人 $50 \sim 60^{\circ} \mathrm{C} に 24$ 時間加熱して得たり、融點 $146 \sim 8^{\circ} \mathrm{C}$ 少 (VI)にナトリウムフェノォキサイドな低溫にて作 用せしめて同物質か得たり、又 $\alpha . \alpha^{\prime}$ ダプロモアヂピ ン酸ーヂー $\beta$ フチルエステルは (VI) に ルを作用せしめて得たり、收量は何れも良好ならず (Reynold C. Fuson, Oscar R. Kreimeier and Gilbert L. Nimmo, J. Amer. Chem. Soc., 1930,52, 4074)

\section{ポリヒドロオキシ脂肪酸の加熱に依る行黨に就て}

融點 $133^{\circ} \mathrm{C}$ の 9,10 ・デヒドロオキンステアリン酸 (I)炭酸瓦斯氣流中に於て $300^{\circ} \mathrm{C}$ に加熱すれば 3 時閒目頃より溜出物な得らろ、之ねェーテルにて探り アルコールより再結晶するに融點 $72 \sim 73^{\circ} \mathrm{C}$ 示し
10ーケトステアリン酸(IV)なろ事か磪めたり、收量は 理論數の 50 ～60\% に當乃、本物質は薄片狀結晶にて 冷アルコールに難溶なり、佾 (I) ね前記同榜にして $200 \frown \mathrm{C}$ に熱する時は 15 時間に $9.43 \%$ の水方分解し ファクチス樣物質よなりアルコール、エーテル、ベン ゾール、アセトン等に溶解せず、次に之ね $310 \sim 320^{\circ} \mathrm{C}$ に加熱すれば 10ーケトステアリジ酸か溜山し來ろ、融 點低き $\left(c 8^{\circ} \mathrm{C}\right)(\mathrm{I})$ 合以てすれば 10ーケトステアリン酸 の生成容易なり、以上の反應に就き著者等は次の如く 誈明せり、即ち(I)は加熱に依りエストリド (II)か生 成し、之ね更に强熱すれば再び (I)占生じ同時に一方 に10ーオキシー9・10ーオレイン酸(III)各生成し(III)は 分子內轉移に依り 10ーケトステアリン酸（IV)に變ず と、即ち次式の如し

$\mathrm{CH}_{3} \cdot\left(\mathrm{CH}_{2}\right)_{7} \cdot \mathrm{CHOH} \cdot \mathrm{CHOH} \cdot\left(\mathrm{CH}_{2}\right)_{7} \cdot \mathrm{COOH}$ $\mathrm{CH}_{3} \cdot\left(\mathrm{CH}_{2}\right)_{7} \cdot \mathrm{CHOH} \cdot \mathrm{CHOH} \cdot\left(\mathrm{CH}_{2}\right)_{7} \cdot \mathrm{COOH} \overrightarrow{\mathrm{H}}$<smiles>CCCCCC(O)CCC(=O)OCC(=O)CCC</smiles>

$\mathrm{CH}_{3} \cdot\left(\mathrm{CH}_{2}\right)_{7} \cdot \mathrm{COH}=\mathrm{CH} \cdot\left(\mathrm{CH}_{2}\right)_{7} \cdot \mathrm{COOH}$

$\rightarrow \quad+$ (III)

$\mathrm{CH}_{3} \cdot\left(\mathrm{CH}_{2}\right)_{7} \cdot \mathrm{CHOH} \cdot \mathrm{CHOH} \cdot\left(\mathrm{CH}_{2}\right)_{7} \cdot \mathrm{COOH}$

$\rightarrow \mathrm{CH}_{3} \cdot\left(\mathrm{CH}_{2}\right)_{7} \cdot \mathrm{CO} \cdot \mathrm{CH}_{2} \cdot\left(\mathrm{CH}_{2}\right)_{7} \cdot \mathrm{COOH}$

(IV)

著者等は更にサチヴイン酸（四七ドロオキシステア リン酸) 及びリヌシン酸（六七ドロオキシステアリン 酸）に就て同樣の實驗々行ひたるも相當するヂ及びト リケトステアリン酸后得ずして酸價及ボェステル價低 く沃素僄高き物質る得たり、サチヴイン酸よりは不畧 化物 $35 \%$ (不飽和宸化水素)たリヌシン酸よりは掩發 性不畧化物 (宸化水素) の外揮發性酸も得たり、之等 は $290^{\circ} \mathrm{C}$ 以上に加熱する際その量方急に增加す (K.

H. Bauer und A. Eberle, Angew. Chem., 1930, 43, 902)

ブラジル胡姚油 ブラヂル胡桃種肉は約 $70 \%$ の油

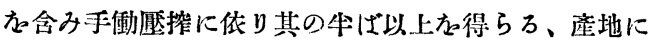
於ては食用、石畧原料、其の他登用として用いらろ、 著者等は該種肉る先づ厴控して油か探り殘渣は更に石 油ェーテルにて抽出し殘留せる油る探れり、其性質次 の如し 
厘 搾 油

\begin{tabular}{|c|c|c|}
\hline 比 重 $25^{\circ} / 25^{\circ}$ & 0.9150 & 0.9143 \\
\hline 屈折率 $20^{\circ}$ & 1.4678 & 1.4683 \\
\hline Titer test & - & 33.3 \\
\hline 沃素價(ウィキス) & 99.92 & 95.21 \\
\hline 羷 化 價. & 194.0 & 193.0 \\
\hline エステル價 & 193.9 & 193.8 \\
\hline ライヘルト・マイスル價 & 0.0 & 0.31 \\
\hline ボレンスケ價 & 0.0 & 0.32 \\
\hline 推離脂肪酸 $\left(\begin{array}{l}\text { オレインて酸 } \\
\text { として\% }\end{array}\right)$ & 0.006 & 0.02 \\
\hline ア七チル價 & 12.3 & 12.3 \\
\hline 可溶性酸(酪酸％) & 0.87 & 0.56 \\
\hline 不溶性酸 \%) & 94.16 & 93.88 \\
\hline 不飽 和 酸（\%) & 73.00 & 70.10 \\
\hline 飽 和 酸(\%) & 20.29 & 21.36 \\
\hline 不飽和酸の沃素價 & 129.18 & 127.92 \\
\hline 瞼化價 & 199.6 & 201.2 \\
\hline 不 㽞 化 物 & 0.64 & 0.68 \\
\hline
\end{tabular}

不飽和酸占臭素化したるにに六臭化物吕生成せずサノ ール酸四臭化物及びォレイン酸二臭化物る得たり、飽 和酸はメチルェステルとなし蒸溜したるに $\mathrm{C}_{12}$ より $\mathrm{C}_{18}$ 迄の酸のエステルより成ら事不知れり、夫等の 組成計算結果は次の如し

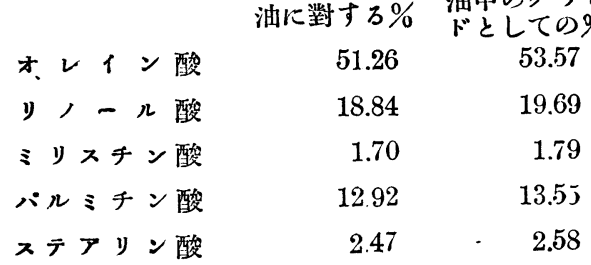

(H. A. Schuette, Ralph W. Thomas and Mabel Duthey, J. Amer. Chem. Soc.. 1930, 52, 4114)

(紀) (折 戶)

Stillingia 脂の成分 脂肋酸はパルミチン酸 57〜 69\%、オレイン酸 21〜34\%、ミリスチン酸 3〜6\%及 びテアリン酸 1〜3\%より成ろトリバルミチンは約 25〜35\%、オレオヂパルミチンは約 $60 \%$ 含有さろ、凝 固點は試料により可なり相違あるも多くは $42 \sim 48^{\circ} \mathrm{C}$ なり、本脂肪は䶂燭又は石畧製造用原料としては優れ たっし食用と篇すにはトリパルミチンの含有量大なれ ば不向なる可し(T. P. Hilditch \& J. Priestman, $J$. S. C. $I, 1930,49,397 \mathrm{~T}$ )

(折 戶)

石䠯の洗淨力測定法 石瞼其の他洗濯液の洗浮作用 の定量的測定は實用的意義各有す万問題にしてこれが
方法は種々提出さろろる未だ定まれろものなし、H. Sturm の提出さ万方法は定量的基楚な有し而も迅速

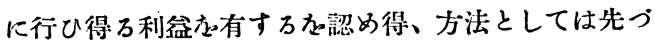
人㑫的なる污染孝纎維に固着せしむ、これがためにフ ランネル告牛時間 $50^{\circ} \mathrm{C} に$ に $1 \%$ 炭酸アムモン液山 にて處理し充分洗滌乾懆後 1qdm の四角形に截㫁す これなビーカー中 $200 \mathrm{ccm}$ の蒸溜水と $20 \mathrm{ccm}$ の鐵ア ムモニウム明礬溶液 ( $1 l$ 中 $8.00 \mathrm{~g}$ 各含む) か以て䓡

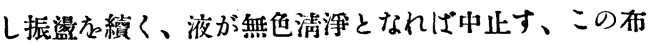
は $25.0 \mathrm{mg}$ の $\mathrm{Fe}_{2} \mathrm{O}_{3}$ 考含む、洗滌實驗は上に得たろ布 え确子棒の四角枠に張りてビーカーに浸し $90^{\circ} \mathrm{C}, 1 \%$ 石鹼液中にて 1 分間 100 迴轉の速度にし 15 分問洗

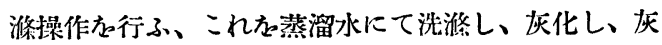
分中の酸化鐵る゙ンマーマンーラインハルト法に依り 定量す、かくして得たる鐵の量々布中最初に沈澱さし めざろ量より減じて洗淨量とす、通常これな並行的に 行ひて比較武驗长行子

實驗結果として

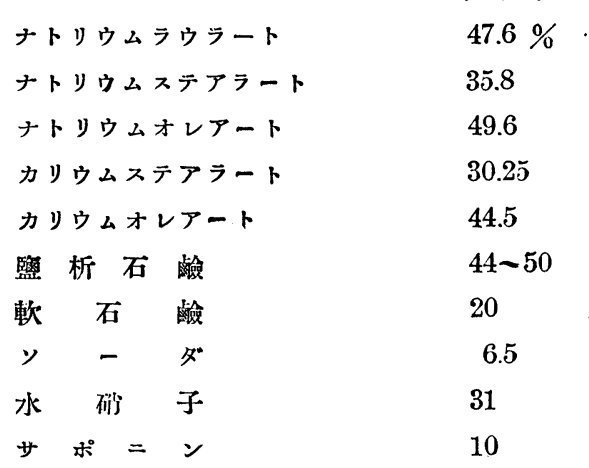

向他の實驗例に於ては監析石豴は $90^{\circ} \mathrm{C} に 0.4 \%$ な最も適當とし洗浮溫度の低き程一定の價か得ちは困 難なり、大體沙淨作用は $90^{\circ} \mathrm{C}$ の場合は $25^{\circ} \mathrm{C}$ の時の 2 倍なり、石畧に過硼酸え加へたる場合は洗淨僄占低 下せしも、これまて行はれたるる方法としては脂肪含有 污染の方法あれども酸化銅法より困難なり (E. Bosshard und H. Sturm, Chem. Ztg., 1930, 79, 762)

(河 村)

\section{4. 香料油及香料}

\section{アルカリ溶液內に於けるピペリトンの 自働酸化}

50〜75g の加里た 250cc の純メタノール中に溶解し 次に同溶液な 750cc 入の酸化装置 (Ente) 內に於て $100 \mathrm{~g}$ のヒペリトンと酸素とにて振盓せり、其際同装 置は灌浿法に依り冷却せられなる如くなれり、實驗の 
結果 3〜6 時間後に振洫速度に應じて $16 l$ の酸素吉消 費せり反應液の色は染褐色呈しピペリトンの香氣は 失はれ弱きフェノールの香氣艻有せり、同液长水蒸氣 蒸溜媵油分々ェーテルにて抽出し、得た万油分 (收率

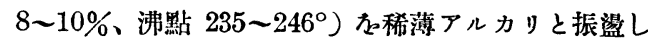

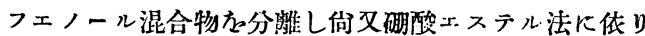
精製し次の如き恒數应示するの得けり、即ち $d_{15}^{2)}=$ 0.9870 , 沸點 $235^{\circ}$ ，フェニールウレタンの融點 110

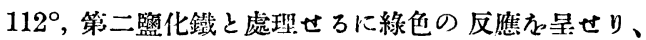
以上の點より本フェノールはチモーえと異万别個のン エノールにして恐らくチモ七ドロキノンに非ろか、水 蒸氣蒸溜の際殘れ万溶液は硫酸にて酸性とし更に水蒸 氣蒸溜方行ひ、得られたる黃色の油かェーテルにて抽 出し、次いてェーテルを驅逐後アルカリと振波せろに 極く少量の部分がアルカリ液中に移れるか恝めたり、 次いて同アルカリ液吉稀薄硫酸と處理し油狀遊離酸店 得、同酸吉分溜せるに $15 \mathrm{~mm}$ にて $125^{\circ} \sim 145^{\circ}$ にて溜

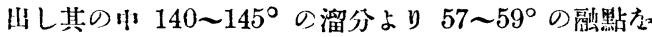
有すっもの得たり、臭化㵋、酸價よりして $\mathrm{C}_{10} \mathrm{H}_{16} \mathrm{O}_{2}$ な万分子式有寸万ものなること推定せり、又上記 中のアルカリに溶けざ万酸性溶液の部䓃蒸溜し油分か 得たり、次に其の恒數方示さば沸點 246〜248 $120^{\circ},(13 \mathrm{~mm}) d_{15}^{2 !}=1.010$, 同油分に就て少種々賽驗龙 行へろ結果 $\mathrm{C}_{10} \mathrm{H}_{16} \mathrm{O}_{2}$ なろ分子式方有すろラクトン なることな知れり、同ラクトンは曹達溶液と煮沸する

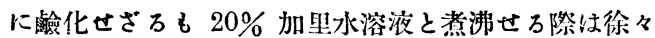

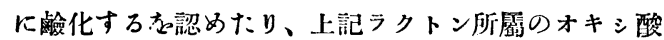
は性狀結晶にして䖲點 $113^{\circ} \sim 114^{\circ}$, 分子式 $\mathrm{C}_{10} \mathrm{H}_{18} \mathrm{O}_{3}$ なり、次に同ラクトンかメテル又はメチルアルコール 內にてンヂウムと處理し主としてグリコール后得、其

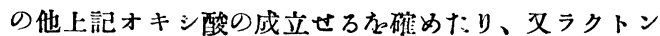
の副產物として得けっ上記不飽和酸㤂此のォキシ酸よ り合成せり (W. Treibs, Ber., 1930, 63, 2423)

(例 藤)

ピベリトンの光化祭的重合 石英光に依 万場合一 $20 \mathrm{cc}$ の純ピペリトンが水醋酸又はェチルアルコール $60 \mathrm{cc}$ と蒸溜水 $45 \mathrm{cc}$ との混合液中に溶解しこれた。 6 箇の石英确子器中に入れ之等と水にて冷却せられたる 石英水銀ランプの周圍 $1 \mathrm{~cm}$ の距離に於て同光線にさ らせり、11.つ其の場合空氣中に於け万時と水素氣中に 於け万際とね比較せしに綃果に於て何等異ることなき 艻認めたり、同光線に䀧露中最初の數時問後に於ては 小針狀の結晶の集皘杂見、この際これ繰返し吸收濾 過せり、19 時間後に於ては最早小針狀の 結晶各生ぜ
ずして黃色の油方分離せり、次いで同反應物の揮發性 の部分か水蒸氣にて追ひ殘りの油狀物質か溫アルコー ルK溶解し之方冷却し小針狀結晶物㤂析出せしめた り、實驗に於て得らろ〉其の總量は $2.5 \mathrm{~g}$ な、同物 質は一見單一物の如 き 感お口て約 $365^{\circ}$ К沸滕し $112^{\circ}$ にて熔啒せり、次に同油のせミカルバジンの製造實驗 に於て針狀、正方形及び板狀等の複合絬晶物方得たり、 これをメタノールにて數回再結晶品行ひ三つの部分に 分ちたり、更に著者法此の各部に就ての性狀虑研究せ ろに三者は何れもピペリトンの二重結合の異性能なる こと志認めたるも(1)針狀結晶の物と（2)菜片狀の物は 如何な万條件の下にてもセミカルバゾンか作らざるな り、但し雨者の混融㤫行ひたるに著しき融點の降下を 見たることょり兩者の全く異るしのなることを知りた り、次に (2)絹光澤存有寸万針狀結晶物のみ七ミカル

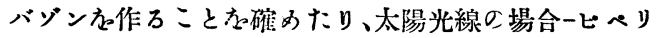
トン100cc ねメタノール200cc と蒸溜水 $30 \mathrm{cc}$ の混合 液中に溶しェナ确子器中に入れ 10 週間太陽光線に䀧 せる同液の色は黄色となれり、この液より前賽驗に於 て得た（1）針狀結晶物と全く同一の物な探り出すこと 杂得たり、得量は $3 \mathrm{~g}$ なりき、份母液に就ては粘液質 (15g)にして 200〜250 (13mm) の沸點にして之より メタノール方加人極めて少量の結晶物品得たり（W. Treibs, Ber., 1930, 63, 2738) （桝 藤）

\section{ジャスミンアルデヒドの安定度と香氣 ジャスミン} アルデヒドの香氣の安定度はそれ自身の酸化作用とは 關倸のないるのである、元來この物質は他の香料と共

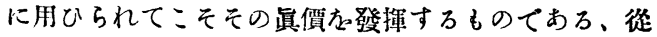
つて香氣の安定度に就ては以上の事柄虑顧みないて考 へろことは出來ない、實際に用ひられると同樣に他の 香料方以て調合したるのに就て實驗した結果は香氣の 惡變はアルデヒドのみのものも調合したものもその程 度に差が認められないことがわかつた、換言すれは酸 化作用が香氣變化に關係ないことが稍明かになつた、 そして香氮の變化はェナントールの痕跡又はベンザル デヒドの痕䟢に原因されるものてもない、クライゼン 反應のと录に副生寸ろデイェナントアルデヒド及び類 似の物質に依るものてはなからうか(Otto Gerhardt, D. P. Z., 1930,20, 468) (岡 本)

\section{6. 護謨}

讙謨のニ、三の基本問題に就て 本篇はコルヴイン 唧賞講演の一として著者の記載せるものにして第 1 篇 は Trans. Inst. Rub. Ind., 1929, 5, 184 にあり、本 
篇は第 2 篇なり、內容は (1)護謨の構造、先つ護謨構 造に關寸万諸家の研究占記載し次に護讙/構造か溶劑 によろ膨脹より推諭し護謨と poly:tyrene との關係 か諭じ polystyrene の膨脹より其の弾性か諭じ次い て擴散謢謨に就きて述ベッ゙ルラバー、ゲルラバー龙記 し次いで重合體の彈性を有することね述へ、X ray diffraction patte: $\mathrm{n}$ ね述べたり (2) 加硫、護謨と硫 黄との作用ょりして加硫の行はれ.3有樣方各段階に亘 りて考察し護謨硫黃との反應と脂肪油硫黄との反應の 相對的なろとょり出發して脂肪油と硫黄との加硫点述 べ漸次に之が加硫に當りて重合か起すことね諭じ重合 觸媒として一般に使用せらろろ benzoyl peroxide は 護謨硫黄の加硫促進劑にして重合の負触媒なる七ドロ キノンは加硫促進劑ならざることの點よりして護謨硫 黃の加硫に當りては重合を件ふことな諭述結論せり

(G. S Whitby, Trans. Inst. R.b. Ind, 1930, 6, 40)

(遠 藤)

新浭度測定器に就て 著者等は R. A. B. R. M.
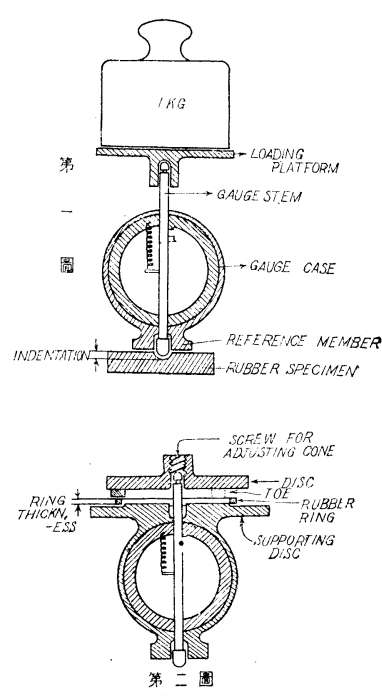

(Research Assoc. of Rubber Manufacturers）型と利 すべき新硬度計な考 案さり、第一國は其 の內部の構造々圖示 寸っものなり、而し て本器の原理、試料 調製方法、使用方法 等に就て䑕明し併世 て從來使用られる万 硬度剖殊にPusey \& Jones Plastmeter とその精磪度な比較 攻究せり、次に本器 なとの上部の重量ち

取り去り批断力測定用ショッパーリングの厚さの測定 方法及びリングの切斷せられたる際のセット測定方法 等につきて記载せり(H. A. Daynes, E. B. Johnson \& J. R. Scott, Trans. Inst. Rub. Ind., 1930, 6, 63)

ミネラルプラックの精䌘と堌强其の他の性質に就て 英國ノースディーボン地方に產出するミネラルブラ ックけ既に Langton(Indust. Chem., 1928, 4, 311) の記載あり、ビツドフォードブラックの名の下に古く ネルンン時代に於けろ船繿塗料用として使用せられ居
たろものにして原未精製物質はその乾燥狀態に於て 1/3 カーボン、 $1 / 3$ アルミナ、1/3 シリカより成る、次 に此の精製法え記せり、粕製物質は $2 / 3$ カーボン、 $1 / 3$ 灰分なり、精製物化學組成は水分 $0.7 \%$ 、アセ卜 ン抽出物 $0.33 \%$ 、比重 $1.75 \sim 1.78$ ，見繁比重 0.5 な り、少その他の性質例へばチンチング武驗、吸收試驗、 分散性質虑記載せり、次にこのカーボンが護䚿に混和 し（1）張力㑡長曲線及び增强效果より一般的に本質を 究めんとし、(2)種々型式の工業用混和に應用して見た り、結諭としては精製ビツドフォードブラックはその 增强能力はランプブラックより大なるもガスブラック の 40\% に當ろ、ガスブラックとは異りて加犊を減退 せしめず、酎老化良好なり、老化䏚止作用家小詐有す、 或乃種の混合にありてはランプブラックの代用にし 得、ガスブラックの際は使用すろガスブラックの 25 \%れビッドフォードブラックにて代用し得るものなり と (P. Schidrowitz \& M. Philpott, Trans. Inst. kub. Ind, 1930, 6, 96)

(暹 藤)

\section{8. 糖類、澱枌及其他の炭水化物} ๙-列アルキルピオシトの直接慗法 (アッェトハロゲ ン糖に對する水銀監の作用 IV) アッェトブロムツェ ロビオーゼに酰酸水银の存在に於てフェノール、チク ロへキサノールか作用させれば $几$ 列の化合物が得ら れろ、この反應方他に及任すに、時に純粹の $\alpha$ 化合物 が得られろが焦々同じ實驗を繰返すことが出來ない場

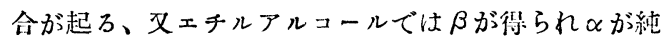
粹に得られなかつた、之等の關係々碓めろために使用

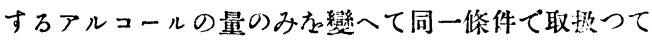
見たのにそのアルコール量如何に依つて $\alpha$ - $\beta$-型 のものが得られることが制つた、例へばンチルッェ ビオシドの場合ならば河榡存 100\%過剩に用ひた時に $\alpha$ 化合物が得られる而して $300 \%$ 過剩に用子万場合と $400 \%$ 過剩に用ふろ場合即ち $10 \mathrm{~g}$ のアッェトブロムツ ェロビオーゼに経し $0.75 \mathrm{~g}$ の酒精の差で以て生成物の 旋光度が $+50.86^{\circ}$ から $-18.26^{\circ}$ に變万ことが制つ た份その他多くのアルコールが試みたが何れも約100 $\%$ 過剩に用ふ万時に $\alpha$ 化命物がうまく得られろ、 $\beta$

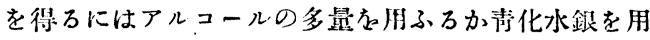
ひてやれば好い(Géza Zemplén und Arpád Gerecs, Ber., 1930, 63, 2720) （突戶沓）

ヘキソーセの奥秦酸化の際にカルボナート添加の影

糖類方臭素て酸化すろには普通長時間九另す万の てあろが酸化に際して臭絷は臭化水素酸になることに 
着目して之なカルボナートで除き反應后促進させよう と試みた、從來からもカルポナートの添加は行はれて ஓたのてあろがそれは繊維素や港粉などの場合に、生 じホ酸が加水分解作用かするのか防ぐのが目的でまつ ホ、例へば $10 \mathrm{~g}$ の葡蒛糖か $150 \mathrm{cc}$ の水に溶かし $10 \mathrm{~g}$ の臭素之少し過剩の炭酸石质古加ふれば 5 分て反隼が 終り收量 $63 \%$ でグルコン酸石庆の結晶が得られろ (M. Hönig und W. Ruziczka, Bzr., 1930, 63, 1618) (宾戶圭)

アピオーゼの講造と配置 パセリのグリコシド、ア ピインより得られろアピォーゼの軣啮に就てはフォン ゲリヒテン氏は之方䋰酸化して得られるアピオン酸 わ沃化水素酸で還元して生成するものがイン結草酸て あるとして $\left(\mathrm{HOH}_{2} \mathrm{C}\right)_{2} \mathrm{C}(\mathrm{OH}) \cdot \mathrm{CHOH} \cdot \mathrm{CHO}$ なる 式各與へたが十分に磪かめられてかなかつた、著者が 之虏碓かめたのにフォンゲリヒテン尤の構造が正しか つた、更にその配置はこのものが二つの宸謷のみ不㔖 であろことに注目すればアピオン酸な取つて次の㮏な

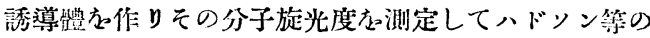
規則に依つて定めろことが出来乃、即ちその旋光度は

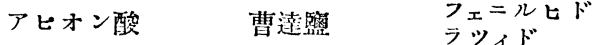

$$
\begin{aligned}
& \begin{array}{lll}
-33.2 & -2.45 & +76.8
\end{array}
\end{aligned}
$$

$$
\begin{aligned}
& \text { *HO でおつて酸 } \rightarrow \text { 籃 } \rightarrow \text { } \\
& \left(\mathrm{HOH}_{2} \mathrm{C}\right)_{2}=\stackrel{\mathrm{C}}{\mathrm{C}}-\mathrm{OH}
\end{aligned}
$$
その配置は.上の樣でおろ (Ott) Th. Schmidt, Ann., 1930, 483, 115)

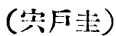

白搪分析法 最近白糖の分析には從來の化學的方法

\begin{tabular}{|c|c|c|c|c|c|c|}
\hline & \multicolumn{4}{|c|}{ 化學的分析 } & \multicolumn{2}{|c|}{ 物理的分析 } \\
\hline & $\begin{array}{c}\text { 水分 } \\
\%\end{array}$ & $\begin{array}{l}\text { 檢糖 } \\
\text { 度 }\end{array}$ & $\begin{array}{l}\text { 轉化 } \\
\text { 糖\% }\end{array}$ & $\begin{array}{c}\text { 灰分 } \\
\%\end{array}$ & $\begin{array}{l}\text { 發光 } \\
\text { 度 }\end{array}$ & $\begin{array}{l}\text { カラ } \\
\text { ル試驗 }\end{array}$ \\
\hline 糖 & 0.033 & 99.48 & 0.005 & 0.009 & 4 & 0.49 \\
\hline 糖 & 0.038 & 99.82 & 0.002 & 0.0125 & 8 & 0.72 \\
\hline 双目糖 & 0.029 & 99.80 & 0.005 & 0.0102 & 11 & 0.85 \\
\hline 星用精糖 & 0.046 & 99.77 & 0.017 & 0.0158 & 314 & 1.52 \\
\hline ラ = 糖 & 0.033 & 99.75 & 0.041 & 0.0276 & 19 & 2.60 \\
\hline
\end{tabular}
に加ふっに物理的方法を探用することとなり、品質上 の差暴在來法よりも制然と區别し得るに至れり、 B. Zimmerman 氏は 5 種類の歐洲精製糖に就て化學 的分析と物理的分析々九行ひ、其の成績ね次の如く示 せり

註 (1) 水分\% は $80 \sim 90^{\circ} \mathrm{C}$ の鱼空乾燥器にて测定 せ

(2) 檢糖度は $20^{\circ} \mathrm{C}$ 測度のものなり

（3）轉化糖\%は Kraizy 氏の所謂微量分析法に
よれり、本法はフェーリング溶液法よりも 正磪なるものなり

（4）灰分\%测定には電氣專導裝置か用ひたり

（5）發光度测定には標潐として蒸溜水㤂用ひサ ンデラ氏装置にて規定水溶液ね以てさり

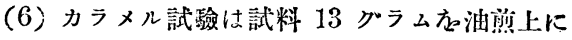
て30 分問 100 170 C K熱し.之れる50cc の水にとかし其の成績かスタンマ一色度る 以て示せり

（7）上表には示さざろも更に規定溶液の光線吸 收曲線点ポーラリグラフィツク曲線として 示しかれり

糖度 99.7ー99.99 白糖の品質无鑑定するには從來の 化學的方法は不充分なるもこの新しき物理的方法は甚 だ適切有效なるものなり (I. S. J., 1930, 583)

(宇井)

\section{2. 爆發物及燐寸}

琴化無烟火燕の感度，渚者认無烟火燕の加熱干燥は 其衙揧感度に皮す影響につき賽驗を行へり、試料とし ては厚さ $0.7 \mathrm{~mm}$ 、等素量 $12.7 \%$ の帶状火藥と厚さ 0.3 $2 \mathrm{~mm}$ 、窒素量 $13.0 \%$ の片狀火覍との新鮮なる製品㤂 用ひ此等方何れも $0.05 \mathrm{~g}$ 宛取り麗氣干燥爐山に30〜 $100^{\circ} \mathrm{C}$ の種々なる浛度に 6〜72 時閒の種々なる時閒加 熐し夫々につき落鎚試驗龙行ひ其結果として加熱干燥 によろ火菜の重量減少上街娐感度の上昨が常に平行す ろ事か見たり、是れ感度が火寡の含屯水分及揮發成分 によりて影響さろ」事立びに $100^{\circ} \mathrm{C}$ 以下の低温度に

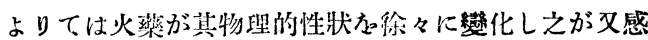
度に影響すべき后思はしむ、同時に此加熱せられたる 試料につき行へろ發火點試驗によれば基發火點は加熱 にょりて著しく熱化せず著者は本賽驗の結果無烟火亚 の年啮及酎使用限度決定の便法たり得べしと提唱さり (M. Tarlé, Z. ges. Schiess \& Sprengst, 1930, 398) (小川)

ナイトログリセリン異㭫能の性質 著者等はナイト ログリセリンの 3 種の異性體即 2 種の固能と 1 種の液

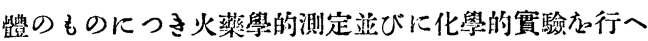
リ、即 5 先づ其等 3 種のブリサンツ試驗、鉛壔試驗並 に爆速測定え行ひ次に不安定異性體の製法及貯藏法々 監じ又結晶速度並に異性體への轉化速度: 異性體の分 子量測定九行ひ此等化學的测定の結果により火萫學的 性質后說明し得万事后示せり(A Dserschkowitsch \& K. Andreew, Z. ges Schiess. \& spreng., 1930, 353)

(小 )!) 